\title{
The HTR Model for Well-Being in Educating Community
}

\section{Elena Falaschi}

Dipartimento di Formazione, Lingue, Intercultura, Letterature e Psicologia, Università degli Studi di Firenze, Italia.

\begin{abstract}
With the aim of enhancing human capital by bringing out talents, this paper offers a theoretical model for innovating teaching/learning methodological approaches. The Humor Talent Resilience (HTR) Model for Well-Being in Educating Community recognizes Humor as a pedagogical device that jointly feeds both Talent and Resilience. This nourishment triggers a dynamic process between Talent and Resilience of reciprocal and constant interdependence, while developing a mutual positive contamination in continuous evolution. This process is itself a "generator of Well-Being" but it will be able to fully convey its educational effectiveness only if it is supported by an Educating Community. While acknowledging the enhancement of all human potentials, including the high or very high potentials, the pedagogy of Well-Being must assume the educational responsibility of offering teaching/learning contexts that allow all students to reach their highest level of development. Three open reflections are presented: the concepts of justice and equity of educational policies and practices aimed at respecting and enhancing all human potentials; the virtual educating (or dis-educating) community; the need for specific training for teachers and more opportunities for international discussion in the field of gifted and talented education.
\end{abstract}

Keywords: Humor; talent; resilience; well-being; educating community; higher education. 


\section{Introduction}

According to the Goal 4 of 2030 Agenda for Sustainable Development ("Ensure inclusive and equitable quality education and promote lifelong learning opportunities for all") it is necessary to offer equitable and inclusive educational opportunities to all individuals, both children and young people in a "lack" situation (emotional, cognitive, linguistic, social, economic) but also to those defined as "gifted and talented", who have a greater potential for development, different from the others, following atypical evolutionary trajectories, at times decidedly deviant or dysfunctional. These characteristics often correspond to invisible, unrecognized needs and rights. The shared European objectives are also those of promoting employment and employability within the European Union and, in a context of economic crisis, enhance the development of talents as reported in the Opinion of the European Economic and Social Committee on "Unleashing the potential of children and young people with high intellectual abilities in the European Union" (Official Journal of the European Union 2013).

\section{The HTR Model for Well-Being in Educating Community}

With the aim of enhancing human capital by bringing out talents, this article offers a theoretical model for innovating teaching/learning processes. The Humor Talent Resilience (HTR) Model for Well-Being in the Educating Community presents Talent and Resilience in their relationship with Humor. Humor constitutes an effective "pedagogical device" (Bateson 1969), understood as a theoretical and operational interpretative category (Foucault 1997) which orients the pedagogical action for the education of human potential (Vygotskij 1987; Montessori 2007). Talent and Resilience are described by highlighting their multifactorial construct and their mutual influence (Cozolino 2008) which, within a systemic-ecologicalsocial context (Bateson 1972; Bronfenbrenner 1979) founded on freedom of choices, contribute to generating Well-Being (Sen 1979) by promoting the values of justice and equity, improving the quality of life (Nussbaum 2007).

The HTR Model for Well-Being in Educating Community represented in Figure 1, recognizes Humor as a pedagogical device that jointly feeds both Talent and Resilience. This nourishment triggers a dynamic process between Talent and Resilience, of reciprocal and constant interdependence, of mutual positive contamination and in continuous evolution. This process is itself a "generator of Well-Being" but it will be able to fully convey its educational effectiveness only if it is supported by an Educating Community. 
Specifically, the present theoretical model describes the constitutive characteristics of the pedagogical device of Humor and of the binomial Talent Resilience in their inter-polytransdisciplinary dimensions (Morin 1999), in their generative potential for Well-Being and in their social connotations.

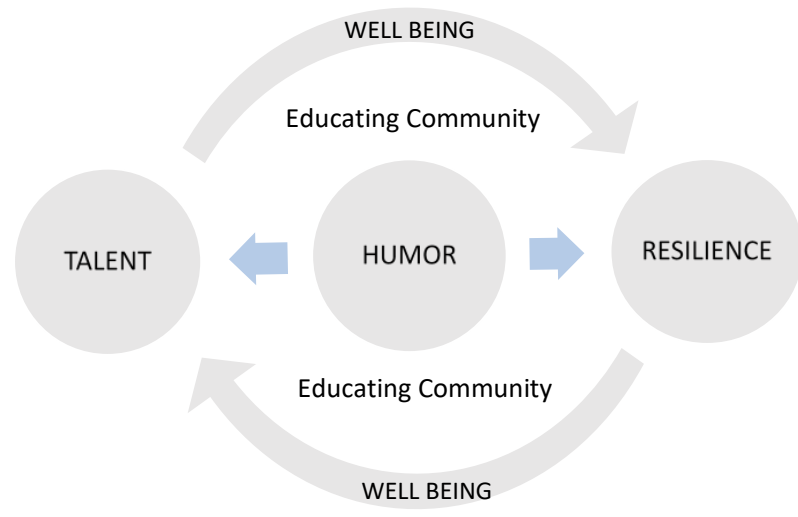

Figure 1. The HTR Model for Well-Being in Educating Community

Humor performs various social and pedagogical functions. Authors Ziv and Gadish (1990) investigated Humor among gifted adolescents and listed all the advantages that teachers can benefit from by using Humor as a teaching tool: reducing the psychological distance between teachers and students; creating a pleasant atmosphere in the classroom with the consequent lowering of psychological tension and conflict; promoting concentration and learning; strengthening the bonds of the group. By avoiding some expressions that offend and hurt (sarcasm and excessively ridiculous behavior), the pedagogical value of the humorous device in teaching/learning processes is easily understood due to its strategic function of enriching human potential, especially of gifted and talented students.

Nowadays, the Talent is described in its quantitative and qualitative connotation as a social product (cognitive, motor, psychological, anthropological), with some universal basic characteristics (biological, neurological and physiological endowment) but highly dependent on culture and experiential learning. In general, gifted and talented students show clearly superior performances to those of their peers already at an early age of development (Sternberg 2004) with strong asynchrony characterized by early and extensive language development, a high ability in abstract reasoning and problem solving, good and sustained attention span, broad interests and high levels of curiosity and intrinsic motivation to learn, intense reactions to frustration, high sensitivity and empathy, frequent use of fantasy and imagination and, in particular, a high sense of Humor.

Several studies (Pinderhughes, Zigler 1985) have confirmed that cognitive intelligence is related to a "sense of Humor". Thus, gifted and talented students have a high sense of Humor, 
understand and appreciate jokes and other more complex forms of humorous stimuli, are able to make very advanced puns, witty ironic remarks and are able to use divergent thinking by capturing humorous aspects in critical and uncomfortable situations. This ability to interpret everyday experiences in a different way must be considered a resource, especially in the educational field, in order to use Humor as a valuable tool for the development of intellectual and creative potential. In this regard, Renzulli's theory of the three rings (2011) confirms the role of three central factors that foster talent: above-average cognitive abilities, creativity and the motivational characteristics of personalities that support commitment. The context plays an essential role in this theory as it is a background that supports, integrates and nourishes any expression of human potential.

Furthermore, the "sense of Humor" was identified by Pourtois et al. (2012) as one of the psychosocial needs among the major indicators of a resilient attitude. In fact, irony is primarily an attitude of the mind, a mode of consciousness, a highly evolved intellectual behavior. While the lack of an openness to irony is a characteristic of many psychopathological conditions as it denotes rigidity, lack of the versatility, restricted mentality and the inability of the subject to grasp the facets of the meanings and distance from itself, highlighting an excess of schematism and a propensity for dogmatism.

A concept of the psychology of emergency (Moran 2006) argues that it is not so much the things themselves that make us feel bad, but the way we perceive them. Therefore Humor, in its relationship with Resilience, offers itself as an effective resource for resizing the event that occurred and reacting more appropriately, since it allows to give alternative meanings to the stressful stimuli. In fact, the wittiest people are more able to enjoy the pleasant aspects of life and feel a sense of less suffering in the face of adversity. Like Talent, Resilience is also a complex construct, based on the interaction of biological, neurological, evolutionary, environmental and cultural factors. According to Rutter (2006) Resilience can be defined as a phenomenon manifested by subjects who carry out a good evolutionary path despite having experienced various forms of trauma, discomfort or stress that could have entailed a serious risk of negative consequences. In order to critically analyze Resilience in its educational forms, it is important to acquire a deconstructive pedagogical sight (Mariani 2008), through hermeneutic procedures of clarification, disambiguation, interpretation of that pedagogical value which, if correctly exercised, can contribute to enriching educational contexts.

In this regard, some authors (Cyrulnik, Malaguti 2005) have identified family and social protection factors (for example the possibility of having a "development tutor" with whom to establish a supportive relationship, a rich social network, a adequate school environment) which, by positively opposing to risk factors, play a decisive role in countering the negative effects of traumatic or stressful events. Furthermore, they identified some individual protection factors (for example, good intelligence, problem-solving-oriented coping, selfesteem, empathy). Among these factors, a fundamental one is knowing how to appreciate and 
use the humorous approach in behavior, communication, relationships, situations. A goodhumor base leads resilient people to appreciate and produce Humor, for the pleasure and Well-Being that it brings and for its power as a "social glue".

The relationship between Humor and Well-Being is very complex (Dijkstra et al. 2011) since Humor is a multidimensional phenomenon consisting of different aspects, uses and functions. Martin and his colleagues (2003) identified four styles of Humor. Two of these styles favor psychosocial Well-Being (affiliative and self-sustaining Humor), while the other two are dangerous and potentially deleterious (aggressive Humor and self-defeating Humor). Individuals who use affiliative and self-sustaining Humor reflect a generally positive outlook on life, a tendency to often be amused by life's inconsistencies and to maintain a humorous perspective even in spite of stress or adversity.

This type of Humor that generates Well-Being is expressed through the transmission "by contagion" of actions, emotions, moods. Some authors (Cozolino 2008) have shown that emotional states are transferred from one individual to another thanks to mirror neurons, involved in the perceptions of the emotions of others. Happy people naturally tend to be the center of their relational cluster, and this would confirm the role of evolution: since we are social animals, we put those who can bring us Well-Being at the center of our network. The conclusions are socially and pedagogically important, because they state that a key factor of our happiness is the happiness of those around us. Neuroscience, through the images obtained with new brain imaging techniques, has made it known that the structure of our brain makes it sociable, inevitably subject to a deep brain-brain bond every time we come into contact with another person. It follows that relationship's shape not only experience, but also biological functions, at the level of circuits and brain centers. It is clear that Well-Being arises from the result of the integration between the biological, psychic and social systems. Therefore, the pedagogy of talents (Falaschi 2019) invites us to focus on the Well-Being of the subject, in its entirety and in its relational networks, involving all the different social spheres in which it is inserted (Falaschi 2017).

Thus, the condition for the HTR Model for Well-Being to demonstrate its educational effectiveness is that it can be operated within an Educating Community, understood as a relational context that integrates and supports all the processes described by the Model. This social condition is necessary because gifted and talented students often report feelings of "high difference" arguing that the recognition of being gifted and talented interfered with full social acceptance implying that this situation can represent a social handicap. Some individuals have also stated that they hide or minimize their visibility as gifted students to others. In line with the true meaning of education, in order to provide equitable educational responses to diversity, it is necessary to provide all students with several and good opportunities on a cognitive, emotional and social plane, so that they can reach the maximum development of their potential. 
The great Polish sociologist Bauman (2000) explores our current need of community, understood as an almost instinctual desire to recognize oneself and to belong to a community, to compensate for the underlying insecurity that is the paradigm of the globalized world. $\mathrm{He}$ argues that community membership is based on a mutually binding sentiment, the true and real strength that allows the citizens of the community to remain united despite the many factors of disintegration. Bauman recalls the concept of "hot circle" to identify the community in a sort of confident immersion in a world made of compactness and human solidarity, of pragmatic bonds of loyalty and fidelity that make "warm" the community circle.

In this direction and in the context of studies dedicated to situated learning and the enhancement of communities of practice (Lave, Wenger 1998), the concept of "resilient community" (Vanistendael, Lecomte 2000) can be interpreted as an educating and supporting community (which is recognized in the sense of belonging to the community, in the sharing of values and beliefs, in internal ties, in the construction of a collective identity, in social support) that constitutes an indispensable protective factor since it activates all the creative potentials and resources present in it. From an ecological perspective (Bronfenbrenner 1979), the assessment of the social resilience of a community must maintain a multidimensional and multi-professional approach (Milani, Ius 2010) and always place itself in different multiperspective disciplinary levels (pedagogy, psychology, sociology, medicine).

\section{Conclusions and discussion: three open reflections}

The arguments presented to describe the HTR Model for Well-Being start from the assumption that a high sense of Humor is a "nourishing" characteristic of both Talent and Resilience and those are based on the demonstration that this combination is a "generator of Well-Being" that feeds itself. There are many contexts (and people) that represent the application of the HTR Model for Well-Being. Some examples: in the work (the charismatic founder of Apple, Steve Jobs), in the disability (the mathematician, physicist and cosmologist, Stephen Hawkins), in the children's literature (the swedish girl, Pippi Långstrump), in the animated films (the family members in The Incredibles - A "normal" family of superheroes). Humor (curiosity, optimism, smile) and Resilience (tenacity, flexibility, risk-taking) characterized these gifted and talented people, who have been able to express their high potential thanks to a state of Well-Being generated within their Educating Community. In compliance with the enhancement of all human potentials, the HTR Model for Well-Being suggests that teachers take the educational responsibility to offer teaching/learning contexts, understood as Educating Community within which the "humorous device" allows gifted and talented students to achieve their highest level of development. 
However, three open questions remain. The first concerns the educational justice, the concept of equity of educational policies and practices aimed at respecting and enhancing all human potential, especially gifted and talented students'one. It is necessary to overcome a distorted conception of the term "equality" since it is not synonymous with "equity": the term equality (or inequality) simply describes a quantitative comparison, while the term equity (or inequity) refers to moral issues, the presence or absence of justice (Nussbaum 2007). Gifted and talented are generally denied educational justice if they fail to receive an education that adequately challenges them (Merry 2008). The core of the second reflection is addressed to the virtual educating (or dis-educating) community. An interesting research (Freeman 2016) examines the positive and negative implications, highlighting some possible effects of electronic social media on the intelligence and emotional development of gifted and talented. In particular, it emerges that social media have positive effects on the defense of talent, on the teaching/learning opportunities for exploration and research, but, at the same time, they imply the risk of encouraging superficial thinking and influencing negatively the personal relationships. Finally, the third reflection underlines the need for specific training for teachers and more opportunities for international discussion in the field of gifted and talented education. The question of "who should teach the gifted and talented" is still at the center of the pedagogical debate. Various studies (David 2011) investigate students' preferences for teachers behaviors. The qualities of teachers appreciated and considered effective by gifted students certainly refer to cognitive and intellectual traits (ability to successfully plan and implement differentiated lessons, apply critical thinking to problem solving) but pose much more importance to personal and social attributes (passionately loving teaching, being an interesting, enthusiastic, self-confident, friendly person, having a sense of humor).

\section{References}

Bateson, G. (1972). Steps to an Ecology of Mind. Chicago: University of Chicago Press.

Bateson, G. (1969). The Position of Humor in Human Communication. Londra: Routledge.

Bauman, Z. (2000). Community: Seeking Safety in an Insecure World. New York: Polity Press.

Bronfenbrenner, U. (1979). The ecology of human development: Experiments by nature and design. Cambridge: Harvard University Press.

Cozolino, L. (2008). The Neuroscience of Human Relationships: Attachment and the Developing Social Brain. Clinical Social Work Journal. 36(1), 113-115. doi: 10.1007/s10615-007-0140-2.

Cyrulnik, B., Malaguti, E. (a cura di) (2005). Costruire la resilienza. La riorganizzazione positiva della vita e la creazione di legami significativi. Trento: Erickson.

David, H. (2011). The Importance of Teachers' Attitude in Nurturing and Educating Gifted Children. Gifted and Talented International. 26(1-2), 71-80. doi: 10.1080/15332276.2011.11673590. 
Dijkstra, P. et al. (2011). Humor Styles and their Relationship to Well-Being among the Gifted. Gifted and Talented International. 26(1-2), 89-98. doi: 10.1080/15332276.2011.11673592.

European Economic and Social Committee. (2013). Unleashing the potential of children and young people with high intellectual abilities in the European Union. Official Journal of the European Union. 01-07. OJ C 76, 14.03.2013.

Falaschi, E. (2017). Il benessere come bene comune. Una forte coscienza filosofica e un fondato impegno pedagogico. Studi Sulla Formazione/Open Journal of Education, 20(1), 95-118. https://doi.org/10.13128/Studi_Formaz-20942.

Falaschi, E. (2019). The epistemological challenge of the "pedagogy of talents": educating for resilience in order not to waste social capital. Studi Sulla Formazione/Open Journal of Education, 22(2), 197-214. https://doi.org/10.13128/ssf-10795.

Foucault, M. (1997). Histoire de la sexualité II. L'usage des plaisirs. Paris: Gallimard.

Freeman, J. (2016). Possible effects of electronic social media on gifted and talented children's intelligence and emotional development. Gifted Education International. 32(2), 165-172. https://doi.org/10.1177/0261429414557591.

Lave, J., Wenger, E. (1998). Communities of practice: Learning, meaning, and identity. Cambridge: Cambridge University Press.

Mariani, A. (2008). La decostruzione in pedagogia. Una frontiera teorico-educativa della postmodernità. Roma: Armando.

Merry, M. S. (2008). Educational justice and the gifted. Theory and Research in Education. 6(1), 47-70. doi: 10.1177/1477878507086730.

Milani, P., Ius, M. (2010). Sotto un cielo di stelle. Educazione, bambini e resilienza, Milano: Raffaello Cortina.

Montessori, M. (2007). Come educare il potenziale umano, Milano: Garzanti.

Moran, C. C. (2006). Coping with Stress: Social Work Students and Humour. Social Work Education. 25(5), 501-517. doi: 10.1080/02615470600738890.

Morin, E. (1999). Les sept savoirs nécessaires à l'éducation du futur. Paris: Seuil.

Nussbaum, M. C. (2007). Frontiers of Justice: Disability, Nationality, Species Membership. Harvard: Harvard University Press.

Pinderhughes, E. E., Zigler, E. (1985). Cognitive and motivational determinants of children's humor responses. Journal of Research in Personality. 19(2), 185-196. https://doi.org/10.1016/0092-6566(85)90027-3.

Pourtois, J.-P. et al. (2012). Les ressources de la résilience, Paris: Presses Universitaires France.

Renzulli, J. S. (2011). What Makes Giftedness?: Reexamining a Definition. Phi Delta Kappan. 92(8), 81-88. https://doi.org/10.1177/003172171109200821.

Rutter, M. (2006). The Promotion of Resilience in the Face of Adversity. In A. Clarke-Stewart \& J. Dunn (Eds.), Families Count: Effects on Child and Adolescent Development. 26-52. Cambridge: Cambridge University Press. doi:10.1017/CBO9780511616259.003.

Sen, A. K. (1979). Collective Choice and Social Welfare. New York: North-Holland. 
Sternberg, R. J. (ed.). (2004). Definitions and conceptions of giftedness. Thousand Oaks: Corwin Press.

Vanistendael, S., Lecomte, J. (2000). Le bonheur est toujours possible: construire la résilience. Montrouge: Bayard.

Vygotskij, L. S. (1987). Il processo cognitivo, Torino: Universale Scientifica Boringhieri.

Ziv, A., Gadish, O. (1990). Humor and Giftedness. Journal for the Education of the Gifted. 13(4), 332-345. https://doi.org/10.1177/016235329001300404. 